\title{
A new partial defence for the mercy killer: revisiting loss of control
}

\author{
BEN LIVINGS ${ }^{1}$
}

\author{
Senior Lecturer in Law, University of New England, Australia
}

\begin{abstract}
Introduction
Murder, as every practitioner of the law knows, though often described as one of the utmost heinousness, is not in fact necessarily so, but consists in a whole bundle of offences of vastly differing degrees of culpability, ranging from brutal cynical and repeated offences like the so called Moors murders to the almost venial, if objectively immoral, 'mercy killing' of a beloved partner. ${ }^{2}$
\end{abstract}

$\mathrm{T}^{\mathrm{t}}$ is a truism to assert that mercy killing amounts to murder under the criminal law of England and Wales, ${ }^{3}$ but this does not reflect reality insofar as a murder conviction is a very unlikely outcome, even where cases are pursued through the criminal justice system. ${ }^{4}$ Of what he terms the 'mystery of the disappearing murderers', Huxtable writes: 'the law is geared towards ensuring that mercy killers reappear in most cases as either assistants in suicide or manslaughterers'. ${ }^{5}$ Each of these routes allows for a more flexible sentencing response than the mandatory life sentence imposed for murder, and avoidance of the imposition of an offence label deemed inappropriate. Whilst they may achieve similar ends,

1 The author wishes to thank Nicola Wake and Amy Purvis for their comments on a draft of this article, and attendees at the 2013 Socio-Legal Studies Association and Society of Legal Scholars annual conferences for helpful discussion of some of the ideas presented here.

$2 \mathrm{R} v$ Howe [1987] 1 AC 417, 433 (Lord Hailsham).

3 As Lord Goff asserts: 'if I kill you from the motive of compassion (so-called mercy killing) I nevertheless intend to kill you and the crime is one of murder' (Lord Goff, 'The Mental Element in the Crime of Murder' (1988) 104 LQR 30).

4 Richard Huxtable, Euthanasia, Ethics and the Law: From Conflict to Compromise (Routledge Cavendish 2007) 36. Until the recent case of $R v$ Inglis [2011] 1 WLR 1110, R v Cocker [1989] Crim LR 740 appears to be the only recent example of a murder conviction.

5 Huxtable (n 4). In the recent case of Kay Gilderdale, the judge was highly critical of the Crown Prosecution Service's decision to bring a case for attempted murder <www.solicitorsjournal.com /news/public/care/prosecuting-mother-attempted-murder-public-interest-dpp-insists $>$ accessed 10 February 2014. 
however, they comprise very different offences, ${ }^{6}$ and my focus here is on the availability of voluntary manslaughter. I shall not engage in any meaningful way with the normative arguments about whether or not mercy killing should be lawful, or indeed broader questions of policy and the criminal law in relation to the end of life, beyond making the relatively uncontentious assumption that murderer is an inappropriate label for a mercy killer in the vast majority of cases, especially in light of the continuing existence of the concomitant mandatory life sentence.

My argument proceeds in three parts. In part 1, I offer a short account of the partial defences; their historical role and some of the perceived inadequacies that fed the changes brought about by the Coroners and Justice Act (CJA) 2009. From here, I look in more detail at the adoption of diminished responsibility as a de facto partial defence for the mercy killer under the law that existed before the inception of the CJA 2009, which stands as a demonstration of the way in which the partial defences serve to protect the defendant from an inappropriate murder conviction.

Part 2 looks at the changes to the partial defences implemented by the CJA 2009 and their potential impact. Much of the discussion here is necessarily speculative, insofar as the appellate courts have yet fully to consider the finer details of the pleas. However, plausible claims have been made in relation to a narrowing effect when it comes to diminished responsibility, which may now exclude mercy killing cases. In light of this possibility, I look to the changes brought in by the new partial defence of loss of control, the impact of which is far less straightforward.

In part 3, I dissect the new plea of loss of control, and challenge the view that it amounts to a more restrictive provision than its predecessor. In so doing, I make two main assertions: firstly, that the wording and structure of loss of control admit the possibility of its successful application to a case of mercy killing; and, secondly, that this is arguably preferable to the situation that had operated under diminished responsibility. Where the benign conspiracy isolated defendants by applying a spurious pathologisation in order to afford them a partial defence, loss of control invariably demands consideration of the social context in which defendants act, and effectively asks jurors whether they might react in the same way, if faced with the circumstances of the defendant. This more overt confrontation of the realities of homicide brings a social calibration that is wholly in keeping with the philosophy underlying the partial defences, and may assist in opening up debates about end of life issues, and thus contribute to resolving how the law should best respond.

\section{The partial defences pre-C]A 2009 and the impetus for change}

The partial defences of 'diminished responsibility' and 'loss of control' (formerly 'provocation') operate to transmute murder into voluntary manslaughter. Aside from the nomenclature, the principal effect of this is in sentencing; instead of the mandatory life sentence afforded to convictions for murder, the judge will have discretion as to the sentence

6 Under s 2 of the Suicide Act 1961, a person found guilty of assisting suicide is liable to imprisonment for up to 14 years. Much has recently been written on the issuance of guidelines by the Director of Public Prosecutions in the wake of the House of Lords' judgment in $\mathrm{R}$ (on the application of Purdy) v DPP [2010] 1 AC 345. For discussion, see: Ben Livings, 'A Right to Assist? Assisted Dying and the Interim Policy' (2010) 74 Journal of Criminal Law 31; Penney Lewis, 'Informal Legal Change on Assisted Suicide: the Policy for Prosecutors' (2011) 31(1) Legal Studies 119. 
to pass. ${ }^{7}$ The partial defences are therefore inextricably linked to the current structure of the law of homicide, as instances of murder where the application of the mandatory life sentence appears too draconic in comparison to the blameworthiness of the defendant's act'. ${ }^{8}$ In addition to their utility to the defendants who successfully plead them, the partial defences serve a symbolic role; as Horder notes, they are intended to further a liberal common good ... the preservation of the humanity of the criminal law'. ${ }^{9}$ In this respect, the Law Commission acknowledges that they are inevitably susceptible to changes in social mores and public opinion, and that this relationship should be symbiotic; neither wholly dependent nor wholly divorced from such forces. ${ }^{10}$ Given their role in mitigating its potential injustice, the Commission observes that, absent 're-examination of the surrounding law of murder', the partial defences are subject to inevitable expansionary pressures. ${ }^{11}$

The reform to the partial defences enacted through the CJA 2009 is largely built upon work by the Law Commission, ${ }^{12}$ which points to longstanding dissatisfaction with their operation. ${ }^{13}$ A major spur to reform, prominent in the work of the Commission and addressed in the legislation, was a perceived gender-bias widely held to subsist under the plea of provocation. This was felt to disadvantage, in particular, women who killed their abusive partners, in respect of whom diminished responsibility was perceived as inappropriate, ${ }^{14}$ and provocation problematic. Here, the typically male response of sudden, reactive anger was privileged over a more typically female 'slow-burn' response born of fear. ${ }^{15}$ Thus, as Norrie explains, 'the abused woman was rather shoe-horned into the defence of provocation, and this led to difficulties in defending her'. ${ }^{16}$ In an attempt to make it more accessible and appropriate to such a defendant, a number of obstacles were

7 Norrie points to differentiation within the mandatory life sentence brought about by the sentencing provisions contained in s 269 of the Criminal Justice Act 2003 and argues that this has brought about 'three degrees of offence seriousness' when it comes to murder. For Norrie, 'the 2003 Act has in symbolic terms chipped away at the notion of one, uniquely serious, crime possessing one, uniquely serious, penalty': Alan Norrie, 'Between Orthodox Subjectivism and Moral Contextualism: Intention and the Consultation Paper' [2006] Criminal Law Review 486.

8 David Ormerod, Smith and Hogan's Criminal Law 13th edn (Oxford University Press 2011) 505. As Reed and Bohlander assert, 'cases of manslaughter because of loss of control and diminished responsibility are in fact nothing but instances of murder where the application of the mandatory life sentence appears too draconic in comparison to the blameworthiness of the defendant's act': Alan Reed and Michael Bohlander, Loss of Control and Diminished Responsibility: Domestic, Comparative and International Perspectives (Ashgate 2011) 1.

9 Jeremy Horder, Homicide and the Politics of Law Reform (Oxford University Press 2012) 202.

10 Law Commission, Partial Defences to Murder (Law Com Report No 290 2004) [3.146]. Any study of the history of the defence of provocation shows that it has changed as public values have changed, and that the change of social attitudes is a gradual process. Public opinion should not necessarily decide what the law should be, for public opinion may not be carefully thought out and the law may itself help to shape public opinion, but it should properly be taken into account.

11 Ibid [2.8].

12 Particularly: ibid; Law Commission, Murder, Manslaughter and Infanticide (Law Com Report No 3042006$).$

13 The Law Commission stated the following: '[T]he terms of section 3 are now, in large measure, effectively ignored and scarcely anyone has a good word for it': Law Com No 290 (n 10) [2.8]. Ormerod describes the partial defences as 'subsist[ing] unsatisfactorily in order to avoid the mandatory life sentence for murder': Ormerod (n 8) 505.

14 As Miles notes, there had long been objections to 'a law which requires such defendants to plead their own mental illness to obtain mitigation, rather than offering them a defence which narrates a story of self-defence against unjustified violence': Jo Miles, 'The Coroners and Justice Act 2009: A “Dog's Breakfast” of Homicide Reform' (2009) 10 Archbold News 6.

15 See, for example, D Nicholson and R Sanghvi, 'Battered Women and Provocation' [1993] Criminal Law Review 728.

16 Alan Norrie, 'The Coroners and Justice Act 2009_-Partial Defences to Murder (1) Loss of Control' [2010] Criminal Law Review 275. 
removed and a specific limb to loss of control developed. An apparently unintended, and yet arguably inevitable, consequence of this has been to expand the possible application of the plea when compared to its predecessor in ways that are explored below.

In eschewing broader and more radical reform, the overriding aims of the criminal law reforms contained in the CJA 2009 are set out in the Explanatory Notes to the Bill, which allude to a desire to 'improve its clarity, fairness and effectiveness' ${ }^{17}$ echoing some of the goals of the Law Commission. ${ }^{18}$ The legislation has kept the basic structure of the partial defences intact, a move criticised by Horder, who suggests that the CJA 2009 amounts to a missed opportunity. ${ }^{19}$ For Horder, the government's 'heavily doctrinal' approach to homicide reform 'mired the law in a bog of ever-thickening legal complexity from which, following the coming into force of the Coroners and Justice Act 2009, there is now little hope of escape'. ${ }^{20}$

Beyond those suggestions which went on to form the substance of the revised partial defences, as enacted in the CJA 2009, the Law Commission considered there to be 'other circumstances which may significantly extenuate moral responsibility for homicide', and offered as an example 'the genuine case of mercy killing', but considered them to be 'outside the terms of our present review'. ${ }^{21}$ Ashworth notes the 'pragmatism' of the Law Commission in this respect, writing: '[a]ny attempt at homicide law reform that includes this topic is likely to meet acute controversy that may well derail the whole project of reform'.22 In House of Lords debates during the passage of the CJA 2009, Lord Lloyd suggested a broad, discretionary approach to the founding of a partial defence (that murder should be mitigated where there are 'extenuating circumstances'), ${ }^{23}$ and referred specifically to mercy killing as a spur to his proposal. In his view, a partial defence deriving from extenuating circumstances 'would provide an answer to the case of mercy killing'. ${ }^{24}$ Lord Lloyd's proposal gained support within the House of Lords, but was not to form part of the CJA

17 Coroners and Justice Bill, Explanatory Notes [15] <www.publications.parliament.uk/pa/ld200809/ ldbills/033/en/09033x-.htm> accessed 10 February 2014.

18 The Law Commission emphasised bringing 'order, fairness and clarity to the law of homicide': Law Com No 304 (n 12) [2.4].

19 For Horder, 'the 2009 Act wrongly retained the partial defence structure left in place by the doctrinal path to reform ushered in by the 1957 Act': Horder (n 9) 199-200).

20 Ibid viii-ix.

21 Law Com No 290 (n 10) [3.63].

22 Andrew Ashworth, 'Principles, pragmatism and the Law Commission's recommendations on homicide law reform' [2007] Criminal Law Review 333.

23 Lord Lloyd's proposed amendment was as follows: 'Murder: extenuating circumstances: (1) In a trial for murder the trial judge may in the course of his summing up direct the jury that if they are satisfied that the defendant is guilty of murder, but are of the opinion that there were extenuating circumstances, they may on returning their verdict add a rider to that effect. (2) The judge may not give such a direction unless there is evidence on which a reasonable jury might so find. (3) Where the jury has so found, the judge shall not be obliged to pass a sentence of life imprisonment but may pass such other sentence as he considers appropriate having regard to any extenuating circumstances found by the jury. (4) If it appears to the Attorney General that the sentence so passed is unduly lenient he may refer it to the Court of Appeal under section 36 of the Criminal Justice Act 1988 (c 33) (reviews of sentencing).’: (HL Deb 30 June 2009, vol 99, col 150.

24 Lord Lloyd also cited: 'difficult cases . . . where a soldier or a policeman fires and kills in the agony of the moment'; 'the case of the battered wife'; and 'awkward cases on the edge of provocation and of diminished responsibility'; he acknowledged that there were probably 'many others': HL Deb 30 June 2009, vol 99, col 152. 
2009. ${ }^{25}$ As a result of the narrow approach to reform, the legislation makes no reference to mercy killing, but the subject resonates in spite of the silence.

\section{A 'BENIGN CONSPIRACY' AND DIMINISHED RESPONSIBILITY AS A DE FACTO HOME FOR THE MERCY KILLER}

Before the coming into force of the CJA 2009, the success of a diminished responsibility plea hinged on being able to establish that the defendant was 'suffering from such abnormality of mind ... as substantially impaired his mental responsibility for his acts and omissions in doing or being a party to the killing. ${ }^{26}$ The strict application of this to the mercy killer can be problematic; as Dell notes, mercy killers tend to display a 'total lack of mental disorder'. ${ }^{27}$ However, the obscure language of s 2 enabled a degree of interpretation that allowed a 'benign conspiracy' to operate between 'psychiatrists, lawyers and judges', in order to bring the mercy killer within the definition. 28 Thus, diminished responsibility became a de facto partial defence for the mercy killer, percolating through the criminal process and diverting the defendant from a murder conviction. As Miles notes, the 'benign conspiracy' extended into aspects of the criminal justice system beyond the application of the substantive criminal law, affecting the practices of the Crown Prosecution Service in 'pleas of guilty to manslaughter on grounds of diminished responsibility'. ${ }^{29}$ Ost describes a 'desire to treat mercy killers with compassion' and points out that 'medicalisation of the mercy killer's behaviour . . . provides this sympathetic legal response with a cloak of respectability' ${ }^{30}$ The effective systematisation of this is evident in the advice given in Blackstone's Criminal Practice: "Mercy killing" can ... be dealt with as manslaughter, where the dilemma which has caused the accused to kill can be said to have given rise to depression or some other medically recognised disorder which can be said to be the cause of an abnormality of mind. 31

25 Lord Pannick said: 'I support this amendment for all the reasons that have been given by the noble and learned Lord, Lord Lloyd of Berwick, and by so many other noble Lords. It is striking indeed that so many lawyers should agree about anything. I would add one further argument in favour of the amendment. We all know that there are occasions when the jury is reluctant to convict, despite compelling evidence that the defendant is guilty of murder. The jury is reluctant to convict because of its concern that on the facts of the case a mandatory life sentence is simply inappropriate. One of the great attractions of the amendment is that it would involve the jury in the assessment of whether there are extenuating circumstances.': HL Deb 30 June 2009, vol 99, col 157.

26 Homicide Act 1957, s 2. This could have arisen 'from a condition of arrested or retarded development of mind or any inherent causes or induced by disease or injury'. In Byrne [1960] 2 QB 396, Lord Parker CJ contrasted 'abnormality of mind' with the expression 'defect of reason' for the purposes of the M'Naghten Rules. The court held that an 'abnormality of mind' was wide enough to cover 'the mind's activities in all its aspects, not only the perception of physical acts and matters, and the ability to form a rational judgement whether an act is right or wrong, but also the ability to exercise willpower to control physical acts in accordance with that rational judgement'.

27 S Dell, 'The Mandatory Sentence and section 2' (1986) 12 Journal of Medical Ethics 28-31, 30. See also: S Dell, Murder into Manslaughter: The Diminished Responsibility Defence in Practice (Oxford University Press 1984).

28 Edward Griew, 'The Future of Diminished Responsibility' [1988] Criminal Law Review 75, 79-80.

29 Although central to the operation of the law and an omnipresent concern in all matters relating to the practical role and function of the criminal law, the wide-reaching influence of prosecutorial discretion is largely outside the remit of this article.

30 Suzanne Ost, 'The De-Medicalisation of Assisted Dying: Is a Less Medicalised Model the Way Forward?' (2010) 18 Medical Law Review 497.

31 David Ormerod et al (eds), Blackstone's Criminal Practice 2012 (Oxford University Press 2011) 186. It should be noted that this advice has not changed since the advent of the CJA 2009; Huxtable cites the same passage which appears in the 2007 edition (Huxtable (n 4) 41). 
The Court of Appeal's recent judgment in $R v$ Inglis is an illustration of the extent to which this approach had become ingrained. ${ }^{32}$ Frances Inglis had killed her son in what she perceived to be an act of mercy, but refused to plead diminished responsibility and was convicted of murder. There are indications in the Court of Appeal's judgment that a diminished responsibility plea may have been accepted, and hints at some consternation that it was not submitted as a partial defence. ${ }^{33}$ To this end, principles derived from diminished responsibility were employed in consideration of sentence: 'In our view her mental responsibility for her actions, driven as she was by a compulsive obsession, was diminished if not sufficiently for the purposes of the defence of diminished responsibility, certainly to an extent that reduced her culpability. 34

Somewhat unsurprisingly, the operation of the benign conspiracy has prompted a mixed response from commentators; whilst Huxtable refers to the outcome as 'often appropriate', ${ }^{35}$ he describes it as a 're-casting' which is 'neither accurate nor fair'. ${ }^{36}$ For Griew, an obvious problem with such an improvised approach is the potential for inconsistency in its application, dependent as it is upon the 'right combination of professionals. ${ }^{37}$ He identifies a number of sources from which this inconsistency may stem:

the less robust or sophisticated psychiatrist ... may not appreciate that the law in its present formal condition is in practice as flexible as it is; so the case may not, pre-trial, be identified as a possible section 2 case. Or the prosecutor or judge may be less sympathetic than some of his colleagues to such liberal use of the section. ${ }^{38}$

Baroness Mallalieu also criticised the operation of the benign conspiracy during debates which preceded the passing of the CJA 2009: 'To watch the judge, the prosecutor and the defence trying to find a way to achieve the right result is not the way justice should be administered. Consistency is needed but so are honesty, openness, clarity and, above all, justice. 39

\section{Reform under the C]A 2009}

In this part, I look at the changes to the partial defences brought about by the CJA 2009. There is good reason to suppose that the reformulated diminished responsibility is narrower in application than its predecessor, and that this may preclude the operation of the benign conspiracy detailed above. However, I suggest that the same cannot be said of the move from provocation to loss of control. Thus, whilst diminished responsibility may no longer be available, there is scope to accommodate the mercy killer within the ambiguous and potentially more expansive loss of control provisions.

In its 2006 report, the Law Commission advocated the modernisation of diminished responsibility, in order to render it 'both clearer and better able to accommodate developments in expert diagnostic practice, ${ }^{40}$ and this is reflected in the CJA 2009. To this end, s 52 made changes to s 2 of the Homicide Act 1957,41 and a successful plea now requires the defendant to prove, on the balance of probabilities, that at the time of the

32 [2010] EWCA Crim 2637. This case was decided according to the situation pre-CJA 2009.

33 Ibid [42] (Lord Judge CJ).

34 Ibid [58] (Lord Judge CJ).

35 Huxtable (n 4) 53.

36 Ibid xv.

37 Griew (n 28) 80.

38 Ibid.

39 HL Deb 30 June 2009, vol 99, col 157 (Baroness Mallalieu).

40 Law Com No 304 (n 12) [5.107].

41 Ss 2(1), (1A) and (1B) of the Homicide Act 1957 were inserted under s 52(1) of the CJA 2009. 
killing he was suffering from an 'abnormality of mental functioning' arising from a 'recognised medical condition', 42 and which provides an explanation for the killing. ${ }^{43}$

There has been broad agreement that the reformulation is narrower in scope and applicability than its predecessor. ${ }^{44}$ Satisfying the demand for 'clarity' in relation to the excusatory ambit of diminished responsibility has the inevitable effect of reducing the discretion available to the courts, and the wider criminal process, to administer justice according to moral standards. Although the practical import of this remains fully to be seen, the regime as it existed under s 2 appears to have moved from being a morally nuanced question (it had, under the previous formulation, been characterised as 'a moral question of degree and essentially one for the jury' $)^{45}$ to one of straightforward medical fact. Fortson and Ormerod agree that this change emphasises the role of the expert over broader value judgment, ${ }^{46}$ and that this will 'create the opportunity for experts to have even greater influence over the outcome'. ${ }^{47}$

Diminished responsibility retains its name, but Mackay argues that the advent of the CJA 2009 amounts to more than a mere modernisation; that it has brought the potential for real change to the doctrine. For Mackay, this 'radical departure from its former self' 48 has resulted in something 'entirely new', 49 and that one effect of this could be to override the benign conspiracy and remove the partial defence from the reach of the mercy killer:

While it is difficult to know whether these differing 'abnormality' requirements will exclude any conditions which might formerly have qualified for a diminished responsibility plea, there is a concern that because 'recognised medical condition' focuses exclusively on the need for a defined and demonstrable clinical condition which is medically recognised, it may fail to include those 'mercy killing' cases which in the past qualified for a s 2 plea. ${ }^{50}$

The future availability of diminished responsibility to mercy killers is unclear. Although Miles speculates that the reforms may preclude the use of the plea, 'resulting in more trials and in more murder convictions, 51 it must be assumed that the desire to avoid murder convictions that manifested in the benign conspiracy outlined above is unlikely to dissipate simply because of the enactment of the CJA 2009, and it may be that the changes therefore have little effect. As Kennefick notes:

42 Homicide Act 1957, s 2, as amended by CJA 2009, s 52.

43 Homicide Act 1957, s 2(1B) as amended by CJA 2009, s 52.

44 Ormerod ( $\mathrm{n}$ 8), goes on to say: 'There is no doubt that the new law is stricter than the original s 2.' 530 Although cf Nicola Wake, 'Recognising Acute Intoxication as Diminished Responsibility? A Comparative Analysis' (2012) 76 Journal of Criminal Law 71-98. Wake examines the possible implications under the new formulation of diminished responsibility for the intoxicated defendant and argues that there may be a widening in application here.

45 Ormerod (n 8) 511.

46 Rudi Fortson, 'The Modern Partial Defence of Diminished Responsibility' in Reed and Bohlander (n 8) 37.

47 Ormerod (n 8) 529.

48 Ronnie Mackay, 'The New Diminished Responsibility Plea: More than Mere Modernisation?' in Reed and Bohlander (n 8) 9.

49 Ronnie Mackay, 'The Coroners and Justice Act 2009-Partial Defences to Murder (2) The New Diminished Responsibility Plea' (2010) Criminal Law Review 290. The requirement for a 'recognised medical condition' was regarded as necessary 'to accommodate future developments in diagnostic practice and encourage defences to be grounded in a valid medical diagnosis linked to the accepted classificatory systems which together encompass the recognised physical, psychiatric and psychological conditions': Ministry of Justice, Murder, Manslaughter and Infanticide (MoJ CP No 19 2008) [49].

50 Mackay (n 48) 16.

51 Although central to the operation of the criminal justice system, the wide-reaching influence of prosecutorial discretion is largely outside the remit of this article. 
Time will tell how the system responds to this particular circumstance in practice. It may well be the case that the courts will likewise stretch their interpretation of the term 'recognised medical condition', or the experts their diagnoses, in order to enable the 'benign conspiracy' to continue, albeit in a slightly different guise. ${ }^{52}$

What follows is predicated upon the possibility that some or all of those mercy killers to whom diminished responsibility was effectively available may be adversely affected by the changes the CJA 2009 made to the plea. In light of this, I suggest that an alternative may lie in the potential breadth of the loss of control provisions brought in under ss 54 and 55 of the CJA 2009 and, further, that this may address some of the complaints that arose in relation to the benign conspiracy, insofar as it would not rely upon the spurious pathologisation of defendants by way of professional collusion. Thus, what the CJA 2009 has taken away, it may simultaneously have reintroduced in a more appropriate form.

\section{FROM PROVOCATION TO LOSS OF CONTROL}

Alongside reform of diminished responsibility, s 56 of the CJA 2009 abolished the partial defence of provocation, which is replaced by a new plea of loss of control. ${ }^{53}$ Throughout its history, the doctrine of provocation had exhibited a somewhat unpredictable development, its political and legal foundations articulated over decades of shifting case law. ${ }^{54}$ At the core of the plea was the relatively stable concept of a 'loss of self-control', as encapsulated in the summing-up in Duffy: 'a sudden and temporary loss of self-control rendering the accused so subject to passion as to make him for the moment not master of his mind'. 55 The law was codified around this core concept in s 3 of the Homicide Act 1957,56 and its legacy lives on in the new plea. Thus, the provisions of the CJA 2009 retain provocation's bipartite structure, comprising what Norrie succinctly refers to as 'a factual and a regulative aspect'; $; 7$ much of the terminology is also retained.

Despite these similarities, the move to loss of control has brought potentially farreaching change. The majority of commentators agree that the plea of loss of control is more restrictive than its predecessor, ${ }^{58}$ and the Explanatory Notes certainly suggest that

52 Louise Kennefick, 'Introducing a New Diminished Responsibility Defence for England and Wales' (2011) 74 Modern Law Review 750.

53 S 56(1) of the Act; s 56(2)(a) provides that s 3 of the Homicide Act 1957, which modified the common law on provocation, ceases to have effect.

54 This is true also of other jurisdictions in which the plea, or a variation of it, plays a role. Of the situation in the US, Nourse writes: 'ideas of provocation have vacillated greatly within criminal law theory': Victoria Nourse 'Reconceptualizing Criminal Law Defenses' (2003) 151 University of Pennsylvania Law Review 1691, 1716.

55 R $v$ Duffy [1945] 1 All ER 932 (Devlin J).

56 Where on a charge of murder there is evidence on which the jury can find that the person charged was provoked (whether by things done or by things said or by both together) to lose his self-control, the question whether the provocation was enough to make a reasonable man do as he did shall be left to be determined by the jury; and in determining that question the jury shall take into account everything both done and said according to the effect which, in their opinion, it would have on a reasonable man.'

57 Alan Norrie, Law and the Beautiful Soul (Glasshouse 2005) 121. As Mitchell notes: 'The new loss of self-control plea is similar to the old common law which it replaces in that it requires defendants to comply with both subjective (viz. a loss of self-control triggered by - in crude terms - fear or anger) and objective (the person of normal tolerance etc.) tests.': Barry Mitchell, 'Loss of Self-Control under the Coroners and Justice Act 2009: Oh No!' in Reed and Bohlander (n 8) 40.

58 For Ormerod, the reforms are designed to be 'a much narrower defence than at common law and under s 3 of the 1957 Act': (n 8) 508. See also: Norrie (n 16); Carol Withey, 'Loss of Control, Loss of Opportunity?' [2011] Criminal Law Review 263. 
this was the legislators' intention. ${ }^{59}$ However, the government described the effect of the legislation as 'raising the bar of the availability [of the partial defence] and extending it to cover those who kill in fear of serious violence as well as those who kill in anger'. ${ }^{60}$ This means that the legislation necessarily pulls in two directions, attempting to constrain whilst at the same time broadening the basis of the partial defence.

Navigating the provisions is not a straightforward exercise; as Lord Judge CJ stated, 'the circumstances in which it is available do not exactly jump off the legislative page'. ${ }^{61}$ Whilst the finer details of loss of control have yet fully to be tested, the case of $\mathrm{R} v$ Clinton $^{62}$ provides an indication of the way in which the courts may approach the plea. ${ }^{63}$ Clinton was not concerned with mercy killing, ${ }^{64}$ but two aspects of the Court of Appeal's judgment provide insight of general application: firstly, the court emphasised that the reforms should be viewed as standalone provisions, divorced from their historical context and the legacy of the moribund doctrine of provocation. ${ }^{65}$ The court warned against any temptation to rely on the extensive case law that attended the erstwhile plea, stating that the provisions of the CJA 2009 relating to loss of control are 'self-contained'. Describing its 'common law heritage' as 'irrelevant' and a part of 'legal history', the court stressed that 'the full ambit of the defence is encompassed within [the new] statutory provisions' ${ }^{66}$

The second aspect of Clinton that is of interest to my present argument is its treatment of legislative provisions that sought to narrow the availability of the partial defence by excluding 'sexual infidelity' as a qualifying trigger for loss of control. The court chooses to construe this exclusion restrictively and justifies this by referring to contextual factors affecting the gravity of the circumstances. For the court, seeking overly to 'compartmentalise' would be 'difficult' and 'unrealistic' and 'carr[y] with it the potential for injustice'. ${ }^{67}$ This amounts to an expansive approach which effectively broadens the availability of loss of control; on this, Wake remarks: 'Judicial law-making appears to have triumphed over the provisions of the statute in this regard. 68

The approach taken in Clinton, juxtaposed with the inescapable similarities between provocation and loss of control, casts the authorities in an interesting light. Together, the pronouncements of the Court of Appeal and the potentially far-reaching reforms brought in by the CJA 2009 give the opportunity for the courts to depart radically from the law

59 Explanatory Note 347 states: 'Subsection (4) therefore sets a very high threshold for the circumstances in which a partial defence is available where a person loses self-control in response to words or actions. The effect is to substantially narrow the potential availability of a partial defence in cases where a loss of control is attributable to things done or said compared to the current partial defence of provocation (where no threshold exists in relation to the provoking circumstances).'

60 A curious statement of the government's intentions in reformulating the partial defences: 'What we therefore sought to do in respect of the change to a provocation defence is to raise the threshold generally, so that those who kill in anger can succeed in having their conviction reduced to manslaughter only in exceptional circumstances. So, we are raising the bar of the availability of that defence and extending it to cover those who kill in fear of serious violence as well as those who kill in anger.': Maria Eagle, Parliamentary UnderSecretary of State for Justice, Hansard Public Bill Committee, Tuesday 3 February 2009.

$61 \mathrm{R} v$ Dawes, Hatter and Bowyer [2013] EWCA Crim 322 [48] (Lord Judge CJ).

$62 \mathrm{R} v$ Clinton and others [2012] 1 Cr App R 26.

63 Ibid.

64 The Court of Appeal looked inter alia at the "extent of the prohibition against "sexual infidelity" as a qualifying trigger for the purposes of the loss of control defence': ibid (Lord Judge CJ). Sexual infidelity is precluded by virtue of s 55(6)(c) of the CJA 2009.

65 The new law can be found in ss 54-55 of the CJA 2009.

$66 \mathrm{R} v$ Clinton and others [2012] $1 \mathrm{Cr}$ App R 26, 364 (Lord Judge CJ).

67 Ibid.

68 See: Nicola Wake in Reed and Bohlander (n 8). 
under provocation. And yet, Clinton also suggests that the appellate courts will act trenchantly in order to ensure that the partial defences are able to mitigate the inflexibility of the law of murder.

\section{Possibilities for the mercy killer under loss of control}

The structure of loss of control largely follows that of provocation, comprising factual and regulatory aspects. In what follows, I analyse the constituent elements of ss 54 and 55 of the CJA 2009, which detail the new plea, and point to the ambiguity they have created. Whilst there are strong indications that the legislators intended for the partial defence to be more narrowly construed than provocation, there is a lack of conceptual certainty in the demand for a loss of self-control and in the 'qualifying triggers' that were introduced ostensibly as a means by which to limit the applicability of the doctrine. Beyond this, there is also ample scope for an empathic response on the part of jurors, who are invited to take a holistic view of the circumstances of the case. These factors combine to make the plea more amenable to a defendant such as the mercy killer. Further, the means by which this is achieved, whilst not optimal, are arguably preferable to the situation as it existed under the benign conspiracy.

\section{THE FACTUAL QUESTION: WHAT IS A LOSS OF CONTROL?}

As was the case with provocation, and contrary to the advice of the Law Commission, ${ }^{69}$ success under the new plea demands that the killing is as a result of the defendant's 'loss of self-control'. At first sight, this requirement presents a significant obstacle for the mercy killer, ${ }^{70}$ as it may appear the very antithesis of their conduct. This point was made recently by the Court of Appeal in Inglis; ${ }^{71}$ whilst this case was decided under the doctrine of provocation, the relevant part of the judgment is worth quoting at length:

There is no doubt at all that the appellant was subjected to great stress and anguish, but dealing with it briefly and starkly, there was, as our analysis of the evidence underlines, not a scintilla of evidence that when the appellant injected the fatal dose of heroin into her son she had lost her self-control. Rather, it was to the contrary: all the evidence demonstrated that the appellant applied her mind to her objective, which was to kill her son, and that she did so with scrupulous and meticulous care, and that in doing so she fulfilled her long-standing objective. Of course, we accept that the appellant is a decent woman, of positive good character, and that acts of violence of any kind, let alone fatal or potentially fatal actions, were quite outside her normal character. However, in relation to her son and his injuries, she was resolved that she should relieve him of his suffering. When she did so, she knew exactly what she was doing, and why she was doing it, and how it was to be done, and how it was imperative that its success should be assured. Far from lacking or losing self-control (an essential ingredient for the defence of provocation) the appellant was completely in control of herself. ${ }^{72}$

The court here formulates a particular view of the exercise of self-control, characterising it as the ability to deliberate and to act in accordance with preconceived intentions; but this

69 Law Com No 304 (n 12) [5.11] and [5.20].

70 The requirements of loss of control are set out in s 54(1): 'Where a person ("D") kills or is a party to the killing of another ("V"), D is not to be convicted of murder if - (a) D's acts and omissions in doing or being a party to the killing resulted from D's loss of self-control; (b) the loss of self-control had a qualifying trigger, and; (c) a person of D's sex and age, with a normal degree of tolerance and self-restraint and in the circumstances of $\mathrm{D}$, might have reacted in the same or in a similar way to D.'

71 [2010] EWCA Crim 2637.

72 Ibid [38] (Lord Judge CJ) [emphasis added]. For discussion of this, see: David Thomas 'Sentencing: MurderMercy Killing' [2011] Criminal Law Review 243, 244-45. 
is not the only possible construction. What is meant by a 'loss of self-control', and the means by which this is measured, were debated in Parliament during the passage of the CJA 2009. Lord Thomas considered the term to be 'ambiguous because it could denote either a failure to exercise self-control or an inability to exercise self-control'. ${ }^{73}$ Herring makes a broader point when he writes: 'An alternative vision of loss of self-control would see it as involving a lack of self-restraint, a lack of "moral check" over one's actions." I4 In this way, a loss of self-control is seen in a social context, as lacking the ability to behave as society expects and demands.

The changes brought in during the transformation from provocation to loss of control reflect in large part a political will to redress the gender disbalance alluded to above, and this is addressed at various points in the legislation. ${ }^{75}$ One of the principal steps taken in order to achieve parity, and accommodate the reality of a more typically female response, was the removal of the requirement that the loss of self-control be 'sudden'. ${ }^{76}$ The Ministry of Justice explained that this 'would allow for situations where the defendant's reaction has been delayed or builds gradually'. ${ }^{77}$ The practical importance of this change has been contested, insofar as it might be difficult to conceive of a loss of control that is not sudden. ${ }^{78}$ However, such criticisms assume that the plea is structured around anger, and are thus rooted in a conventional conception of a loss of self-control (one that is challenged below). For Withey, the change has a much greater significance: 'Separating "loss of selfcontrol" from the concept of "suddenness" and dispensing with the latter requirement could be explained by interpreting loss of self-control as a feeling of being unable to refrain from killing. ${ }^{79}$ Thus, the removal of the suddenness requirement allows for a more expansive conception of a loss of self-control and feeds the ambiguity to which Lord Thomas and Herring allude.

Should the fact of a loss of self-control be established, the defendant's conduct is then subjected to a number of regulatory requirements: it must be as a result of a 'qualifying trigger'; 80 and it must be the case that 'a person of D's sex and age, with a normal degree of tolerance and self-restraint and in the circumstances of $\mathrm{D}$, might have reacted in the same or in a similar way to D'. ${ }^{81}$ As such, these regulatory considerations act to limit both the causes of the loss of self-control that will qualify for the plea, and to calibrate the reaction of the defendant against an expected societal standard.

73 HL Deb, 7 July 2009, vol 712, col 572.

74 Jonathan Herring, Criminal Law 6th edn (Palgrave Macmillan 2009) 160. See also R Holton and S Shute, 'SelfControl in Modern Provocation Defence' (2007) 27 Oxford Journal of Legal Studies 49.

75 For the most part, this has been effected through two elements of the plea: the implementation of the socalled 'fear trigger' and the removal of the requirement that the loss of control be sudden (contained in ss 55(3) and 54(2) respectively).

76 The deliberate nature of this absence is specifically referred to in s 54(2).

77 Ministry of Justice ( $\mathrm{n} 49$ ) [37]. Explaining the reason for resiling from the Law Commission's recommendation that the loss of self-control be done away with entirely, the MoJ said of its proposed change: 'We think this strikes the right balance between addressing the problems identified with the current law whilst not creating new ones.'

78 Norrie (n 16) is sceptical, suggesting that a loss of control will rarely be anything other than 'sudden'; Ormerod makes a similar point, arguing that the removal of the requirement for 'suddenness' may make the defence 'difficult to get off the ground': (n 8) 511-12.

79 Withey (n 58).

80 S 54(1)(b).

81 S 54(1)(c). 


\section{AMBIGUITY AND THE QUALIFYING TRIGGERS: A WIDENING, A NARROWING OR A SHIFT OF FOCUS?}

A prominent means by which the CJA 2009 seeks to regulate the scope of loss of control is by specifying the causes that will qualify. In order to satisfy a case where the plea is raised, the defendant's conduct must be as a result of a 'qualifying trigger', found in s 55(3)-(5). The first of these provides that the defendant's loss of self-control must be 'attributable to D's fear of serious violence from $V$ against $D$ or another identified person'. ${ }^{82}$ The second applies where the loss of self-control is 'attributable to a thing or things done or said (or both) which (a) constituted circumstances of an extremely grave character, and (b) caused $\mathrm{D}$ to have a justifiable sense of being seriously wronged'. ${ }^{83}$

The approach taken in delimiting the 'qualifying triggers' is deliberately and selfevidently exclusionary, insofar as it seeks to exclude any cause of the loss of control that falls outside of their purview. The 'fear trigger' laid out in s 55(3) is narrowly drawn, and in place to avail a defendant such as the abused spouse. The more interesting trigger for the present purpose, and the one that I will argue offers a greater possibility for the expansion of the loss of control plea, and its use by the mercy killer, is that found in s 55(4), a provision with an ambiguity that has thus far been underappreciated. ${ }^{84}$

Section 55(4) has been characterised as the 'anger trigger', ${ }^{85}$ but there is no reference to anger in the loss of control provisions, ${ }^{86}$ and to construe it as such is to view it, not unreasonably, through the lens of the erstwhile provocation. ${ }^{87}$ However, even before the inception of the CJA 2009, commentators had pontificated on the possibility of a range of emotions that might qualify for consideration under the old provocation defence. On this, Herring observed: ' . . . there is nothing in s 3 which would limit the defence to those who lose their self-control through anger'. ${ }^{8}$ Of the mercy killing case of Cocker, he writes: 'the alleged loss of self-control was through compassion, but this was not mentioned as a reason why the defence was unsuccessful'. 89

Whether or not the plea of provocation was centred on a response born of anger, changes brought in by the CJA 2009 may facilitate a shift to a broader view of the qualifying emotions. In what follows, I will demonstrate the extent to which s 55(4) can be decoupled from a narrow anger requirement, and thus overcome one of the perceived obstacles to the success of loss of control claims in mercy-killing cases. In light of this, I shall not refer to the trigger under s 55(4) as the 'anger trigger', but rather as the 'seriously wronged trigger', so as to make room for a more expansive conception of its scope.

Under the reformed plea, the test for establishing the seriously wronged trigger comprises four elements, requiring: (1) 'a thing or things done or said (or both)'; (2) which constitute 'circumstances of an extremely grave character'; (3) that this has caused the

$82 \mathrm{~S} \mathrm{55(3).}$

83 S 55(4). S 55(5) allows for a combination of ss 55(3) and 55(4).

84 Since the inception of the CJA 2009, and indeed dating back to the Law Commission proposals that inspired them, the majority of attention has been focused on the first of the qualifying triggers that may legitimately have caused the 'loss of self-control'.

85 For example, Edwards refers to it as 'the anger defence' (S Edwards, 'Loss of Self-Control: When His Anger is Worth More than Her Fear' in Reed and Bohlander (n 8).

86 This is true both of the legislation and its accompanying Explanatory Notes.

87 In restricting his discussion to fear and anger, Norrie notes the absence of the word 'anger' but makes the reasonable point that 'anger or something like it_-lost temper, outrage-has always been the link between the provoking conduct and the loss of control': Norrie (n 16).

88 Herring (n 74) 160.

89 Ibid 160 . 
defendant to have a 'justifiable sense of being seriously wronged'; and (4) that the defendant's loss of self-control is 'attributable' to the above. Section 55(4) is a direct descendant of the old provocation doctrine, and also draws heavily on the recommendations for reform contained in the work of the Law Commission.

The first of the requirements under the seriously wronged trigger is that the conduct of the defendant must be as a result of a 'thing or things done or said (or both)'. The legacy of provocation is clear in this capacious requirement, ${ }^{90}$ which the Law Commission considered had come to mean "no more than "caused". 91 Writing whether such a requirement might be satisfied in the case of the mercy killer, Taylor is unequivocal: "Surely the answer must be "yes." The illness of the "victim" often manifests itself in numerous acts, often seen by the defendant as being humiliating for the victim. This is further supported if requests are made by the victim to have his/her life ended'. ${ }^{2}$ Should the circumstances of a mercy killing be held to amount to 'things said or done', the second demand of s 55(4) is that this must 'constitute circumstances of an extremely grave character'. Whilst this has a narrowing effect, it is difficult to imagine a situation involving a mercy killing in which this would not be the case. ${ }^{93}$ Insofar as this stands to be appraised by a jury, it will be examined in further detail below.

The third element (a 'justifiable sense of being seriously wronged') amounts to a dual requirement: that the defendant has been 'wronged' and that this sense of being wronged is 'justifiable'. In setting this out, the statute gives no further detail. The ambiguity, moreover, is carried over into the Explanatory Notes. ${ }^{94}$ There is much semantic argument that could be engaged in exploring the exact meaning of 'wronged', and the extent to which this could correlate to the circumstances surrounding a mercy killing. Insofar as the requirement is to be applied to the case of the mercy killer, an intuitive response may be that it cannot, for how is this to be interpreted other than by reference to an aggressor and a person who feels slighted, either by their attitude or actions towards them? A defence that was constrained in such a way would offer little by way of an avenue for the mercy killer, but I suggest that this narrow interpretation is not the only explanation that could find space within this concept. In essence, I suggest that a person can have a sense of being wronged as a result of circumstance, or as a result of decisions taken by people or bodies, and that this can both satisfy the broad requirement of 'things said or done' and induce a reaction that will fulfil the loss of control provisions.

By way of judicial support for this contention, a brief survey of recent appellate cases reveals situations in which the courts have described those who have not been afforded equal treatment under anti-discrimination legislation as having been 'wronged', and reveals

90 S 3 of the Homicide Act 1957 required that 'the person charged was provoked (whether by things done or by things said or by both together)'.

91 Law Com No 290 (n 10) [3.25]. In provocation, it had been established that the things done and/or things said did not need to have emanated from the victim ( $v v$ Davies [1975] QB 691), nor to have been directed at the defendant ( $R v$ Pearson [1992] Criminal Law Review 193; $R v$ Baillie [1995] Criminal Law Review 739).

92 Paul Taylor, 'Provocation and Mercy Killing' [1991] Criminal Law Review 111.

93 If it could be said that a purported mercy killing was taking place absent 'circumstances of an extremely grave character', it is surely the case that either this is not a mercy killing, or that the alternative partial defence of diminished responsibility, or even a plea of insanity, would be more appropriate.

94 Explanatory Note 346 states: 'Subsection (4) sets out when a thing or things done or said (or both) can amount to a qualifying trigger for the loss of self-control. The thing(s) done or said must amount to circumstances of an extremely grave character and cause the defendant to have a justifiable sense of being seriously wronged. Whether a defendant's sense of being seriously wronged is justifiable will be an objective question for a jury to determine (assuming that there is sufficient evidence for the defence to be left to the jury).' 
an assortment of entities and sources from which this may have emanated. ${ }^{95}$ Further examples include the wrongfully convicted; could it not be argued that the wrongful imprisonment of the Birmingham Six led to their feeling 'wronged'?96 Consider further the situation of a parent whose child is denied treatment for a rare condition, the treatment for which is expensive and beyond the scope of the medical authorities; could they not also feel 'wronged'? If such grounds for the sense of feeling wronged are accepted, why not the wrong that is felt when a loved one is suffering and wishes to die? ${ }^{97}$ In all of these situations, it may or may not be possible to point to a person or persons who have brought about the emotion, but such considerations may do little to alter the strength or validity of the emotion experienced, and do not appear to be precluded by the wording of the Act. Should the 'sense of being seriously wronged' extend effectively to cover the invidious situation of the mercy killer, this must also be 'justifiable'. This requirement amounts to one of a number of 'objective' regulatory controls on the plea, to which I will now turn.

\section{OBJECTIVE CALIBRATION: THE REGULATION OF LOSS OF CONTROL}

The exclusionary effect of the qualifying triggers is one means by which the loss of control plea can be regulated. Allied to this, the legislation also precludes use of the plea where the defendant had 'acted in a considered desire for revenge', 98 or had behaved in a way so as to provide 'an excuse to use violence, ${ }^{99}$ or where the trigger 'constituted sexual infidelity'. ${ }^{100}$ The legislation does not expressly preclude mercy killing. ${ }^{101}$

These specific exclusions are buttressed by a number of tests that aim to calibrate the response of the defendant according to societal standards and which are woven into the provisions at various points. The first two of these occur in s 55(4) and were alluded to above: the requirements that the 'thing or things done or said ... constituted circumstances of an extremely grave character ; 102 and that the sense of being seriously wronged is 'justifiable'. ${ }^{103}$ Of the latter requirement, the Explanatory Notes to the CJA 2009 stipulate that this is to be 'an objective question for a jury to determine'. ${ }^{104}$ Whilst it is not specified of the former requirement, it is submitted that this must also amount to an objective appraisal on the part of the jury.

95 Kelly v National University of Ireland (University College, Dublin) (Case C-104/10) [2011] 3 CMLR 36; Tariq v Home Office Supreme Court [2011] UKSC 35, [2011] 3 WLR 322; Donna Marie Arrowsmith v Nottingham Trent University Case No A2/2010/2289 [2011] EWCA Civ 7972011 WL 2039891 ('She believes she has been seriously wronged by Nottingham.' [28]); The Queen on the Application of Mjemer $v$ Secretary of State for the Home Department CO/13206/2010 [2011] EWHC 1514 (Admin) 2011 WL 1151605 (in a report referred to in this case, it is said that individuals may feel 'consistently wronged by the system' [130]); $R$ (on the application of Tate \& Lyle Industries Ltd) $v$ Secretary of State for Energy and Climate Change Court of Appeal (Civil Division) 3 June 2011 [2011] EWCA Civ 664, [2011] ACD 92 ('wronged' by the actions of a public body (279-80)).

$96<$ www.independent.co.uk/news/bond-that-unites-two-wronged-men-men-1164526.html>; $<$ www.independent.co.uk/opinion/leading-article-wronged-people-still-in-the-dock-1371666.html> accessed 10 February 2014.

97 The recent case of Kay Gilderdale provides a good example in this respect <www.solicitorsjournal.com/ news/public/care/prosecuting-mother-attempted-murder-public-interest-dpp-insists $>$ accessed 10 February 2014.

98 S 54(4).

$99 \mathrm{~S} 55(6)$ (a) and (b).

100 S 55(6)(c). See: Rv Clinton and others [2012] 1 Cr App R 26.

101 This 'oversight' is presumably born of an unwillingness to acknowledge the possible relevance of the practice, or an assumption that the provisions exclude it.

102 S 55(4)(a) [emphasis added].

103 S 55(4)(b).

104 Explanatory Note 346. This is subject to the following caveat: 'assuming that there is sufficient evidence for the defence to be left to the jury'. 
Supplementing these requirements is the demand that, in the face of the seriously wronged trigger, a person of a 'normal degree of tolerance and self-restraint . . . might have reacted in the same way' as the defendant. ${ }^{105}$ This ostensibly objective test is tempered by some concessions to the particularities of the defendant, insofar as the loss of control should be viewed according to what might be expected of a 'person of D's sex and age' and 'in the circumstances of D'.

In a piece that is strongly condemnatory of the judgment in Clinton, ${ }^{106}$ Baker and Zhao express the view that the loss of control plea should be construed narrowly, drawing parallels between its inception and the complete abolition of provocation in New Zealand. They assert that the overlapping objective tests should be seen as constrictive, and could be summarised as amounting to a straightforward question for the jury: 'Was it reasonable for the defendant to lose control and kill V?'107 This analysis is problematic; as Fletcher famously wrote, 'the reasonable person does not kill at all, even under provocation'. ${ }^{108}$ In $R v$ Smith, Lord Millett specifically warned against using this standard:

$[\mathrm{f} \mathrm{t}$ can never be reasonable to react to provocation by killing the person responsible. Nor by pleading provocation does the accused claim to have acted reasonably. His case is that he acted unreasonably but only because he was provoked. But while this may not be reasonable it may be understandable, for even normally reasonable people may lose their self-control and react unreasonably if sufficiently provoked. ${ }^{109}$

In suggesting that the defendant's behaviour should be judged against a standard of reasonableness, Baker and Zhao misunderstand the basis of the plea. Where they are more likely to be correct, however, is in their appraisal of the overlap between the different regulatory aspects of loss of control outlined above. These combine to reinforce the idea that a prima facie instance of a loss of self-control as a result of a qualifying trigger should be submitted to further control, comprising a moral question for the jury to assess by reference to 'contemporary society's norms and values . . . the normative standards of a normal person communally situated in Britain'. 110

Any plea of loss of control may founder on judicial discretion, as s 54(6) implements an important recommendation by the Law Commission, namely that the judge should instruct the jury as to whether there is evidence for the defence to stand and to be considered. As Norrie points out, this 'empower[s] judges to make the moral and political call', ${ }^{111}$ but the significance of this potentially onerous requirement is easily overstated. In $\mathrm{R} v$ Dawes, Hatter and Bowyer and in Clinton, the Court of Appeal took a permissive approach to the provision and addressed s 54(6) as primarily a question of evidential sufficiency. ${ }^{112}$ On a conceptual level, it could be said that the test is somewhat redundant. The judge is asked to leave to the jury a determination of loss of control where 'a jury, properly directed,

105 S 54(1)(c).

106 R $v$ Clinton and others [2012] 1 Cr App R 26.

107 Dennis Baker and Lucy Zhao, 'Contributory Qualifying and Non-Qualifying Triggers in the Loss of Control Defence: A Wrong Turn on Sexual Infidelity’ (2012) 76 Journal of Criminal Law 254.

108 George P Fletcher, Rethinking Criminal Law (Little, Brown \& Co 1978) 247.

109 [2000] 3 WLR 654, HL, 712.

110 Baker and Zhao (n 107).

111 Norrie (n 16).

112 In R v Dawes, Hatter and Bowyer [2013] EWCA Crim 322 [53], Lord Judge CJ stated: 'This requires a commonsense judgment based on an analysis of all the evidence . . . the judge should not reject disputed evidence which the jury might choose to believe.' See also: R $v$ Clinton and others [2012] 1 Cr App R 26 [45] and [46]. 
could reasonably conclude that the defence might apply'. Whilst this should rule out fanciful claims, it is of limited assistance insofar as it is tautologically dependent upon the scope of the provisions to which it applies. When it comes to trial judges, the impact of this provision is of course difficult to predict, but their role in the effective operation of the benign conspiracy described above should be borne in mind. ${ }^{113}$

A feature of the loss of control provisions that might give the opportunity for the sympathetic jury to allow the plea lies in its asking whether 'a person of D's sex and age, with a normal degree of tolerance and self-restraint might have reacted in the same or in a similar way to D'. ${ }^{114}$ The question of whether to use the word 'might' in this clause was one upon which the Law Commission equivocated, ruling out the word 'would' on the grounds that a test that incorporated the term would be 'near to impossible' to satisfy. Withey concludes that the use of 'might' has brought a potential expansion, as it makes the test 'easier to satisfy than before': 'Even if most other people would not have reacted in the same or a similar way, if D's reaction was within the response range of other people, unusual and disproportionate responses can be accommodated.' 115

In light of the above, it is somewhat strange that Baker and Zhao downplay the importance of the concessions to subjectivity in the loss of control plea; they assert: 'Considering the defendant's personal circumstances is not likely to add much, but such a consideration might tip the balance in a borderline case.116 Since they concede the importance of the jury's normative view of the defendant's conduct, an invitation to appraise that against a context that may make an enormous difference to how that conduct is perceived is surely of far greater significance than Baker and Zhao entertain. Writing in response to proposals to repeal the partial defence of provocation in New Zealand, Tolmie cites its successful use by a man who 'snapped in response to his mother begging for relief from the pain of the final stages of her terminal bowel cancer and sped up her eventual death';117 Tolmie points to the availability of provocation as 'a concession to human frailty-a recognition that everyone, if the circumstances were extreme enough, could potentially snap and kill'. 118 Where the jury is allowed to factor in a consideration of the 'personal circumstances' of the defendant, this may prove a powerful factor in considering the extremely grave character of the circumstances, the justifiability of the sense of being seriously wronged, and whether a whether a person of a 'normal degree of tolerance and selfrestraint . . . might have reacted in the same way' as the defendant. ${ }^{119}$ Writing of Cocker, ${ }^{120}$ in which the erstwhile plea of provocation was unsuccessfully pleaded, Taylor paints a plausible picture of a jury's probable reasoning when confronted with a mercy-killing case:

113 Though it may not be representative of the views of all trial judges, in such a case, Judge Alan Goldsack, QC, is reported to have said: 'My professional life is spent dealing with criminals. I do not recognise you as a criminal. You pose no risk to anyone. You are not in need of treatment. Despite what you thought on New Year's Day, you still have an important role to play as father and grandfather within your extended family. You should be allowed to get on with it.' (C Brooke, 'Mercy for Husband who Killed Alzheimer's wife "Neglected by Hospital"' The Daily Mail, 27 April 2006, 29).

114 S 54(1)(c) [emphasis added].

115 Withey (n 58) 278.

116 Baker and Zhao (n 107) 271.

$117 \mathrm{~J}$ Tolmie, 'Defence of provocation has its place', New Zealand Herald, 7 September 2009 <www.nzherald.co.nz/justice-system/news/article.cfm?c_id=240\&objectid=10595632> accessed 10 February 2014. The partial defence of provocation (s 169 of the Crime Act 1961) was subsequently repealed, on 8 December 2009, by s 4 of the Crimes (Provocation Repeal) Amendment Act 2009 (2009 No 64).

118 Tolmie (n 117).

119 S 54(1)(c).

120 [1989] Criminal Law Review 740. 
The practicalities of mercy killing cases would probably mean that quite simply the jury, if sufficiently sympathetic to the defendant, would find that he acted as a reasonable man would in the circumstances, and if they are unsympathetic they would not. Much will depend on the facts of the individual case and the last sentence does not necessarily imply that the jury will apply the provocation test incorrectly; it simply means that, as with most cases, it will not be the only thing that the jury take into account in reaching their verdict. ${ }^{121}$

\section{Conclusion}

The legal response to mercy killing is of greater societal importance than can be measured by the quantity of cases appearing before the courts; that this piece has not sought to engage more fully with normative moral, political and social questions reflects the disengaged, yet perversely straightforward, status of mercy killing under the criminal law. Here, it occupies an unresolved space, formally classified as murder and yet rarely prosecuted as such. This invisibility to the substantive law is largely the result of a lack of political engagement that forces the criminal justice system into an improvised response, and the facilitation of the benign conspiracy is symptomatic of the disjunction between the substantive law and the social practice of mercy killing. As Huxtable observes, neither murder nor the application of diminished responsibility 'quite captures the lived, and legal, reality of mercy killing,, 122 and both comprise unsatisfactory responses. It is difficult to disagree with Ashworth's indictment of the legislative stasis that attends the issue: 'The unwillingness of governments to confront this category of cases leaves the law in a state of impoverishment and duplicity.' 123

It may be that the advent of the CJA 2009 forces a change to the prevailing response; the requirement for a 'recognised medical condition', buttressed by the causal requirement also introduced by s 52 of the CJA 2009, may foreclose the use of diminished responsibility. Insofar as this model is unsatisfactory, this is to be welcomed, but it would bring injustice if no other means were available to obviate the often grossly disproportionate effect of a murder conviction. The need for an alternative should prompt a closer examination of the newly introduced plea of loss of control, which might be found to have broader application than has thus far been appreciated.

In asserting the availability of loss of control, there are three hurdles to negotiate, subject to the leave of the judge: firstly, establishing a loss of control; secondly, establishing that the particular circumstances satisfy the qualifying trigger; and, thirdly, the regulatory demands, which appeal to social standards of conduct. Whilst most commentators have looked to its roots in provocation, and the ostensible intentions of the legislature in enacting the loss of control provisions, I have sought to decouple them from the political background and the historical basis of the plea. In so doing, I have shown that both the idea of a loss of self-control and the relevant qualifying trigger under the CJA 2009 can be construed so as to render loss of control potentially broader in effect than its predecessor, and that it may avail the mercy killer.

That is not to advocate an expansive view of loss of control as the best way forward for society or the criminal law. Keating and Bridgeman write of the current state of the partial defences: 'As matters stand this is not a blueprint for a law which responds

121 Taylor (n 92).

122 Huxtable (n 4) 53.

123 Andrew Ashworth ‘Sentencing: Murder-Mercy Killing’ [2011] Criminal Law Review 243, 248. 
appropriately to compassionate killing.' ${ }^{\text {'24 }}$ It is hard to disagree with this point; mercy killing should be considered openly as part of a broader consideration of the important moral, social and legal questions that pertain to issues at the end of life. The adoption of loss of control, which necessitates examination of the defendant's actions against societal standards, may increase the politico-legal visibility of the subject and promote an open debate that is not facilitated by ad hoc and shadowy arrangements between legal and medical practitioners. In the meantime, the partial defences exist to ameliorate the harsher aspects of the law of murder; to exculpate in part those who are deemed less worthy of sanction. Until the subject can be addressed in a more honest and thorough way, their use can and should include those who have committed the sort of 'almost venial' homicide that may be personified by mercy killing. ${ }^{125}$ 